\title{
COVID-19 and the myth of security
}

\section{Lily Hamourtziadou and Jonathan Jackson}

In April 1946, the former leaders of the Nazi regime faced trial at Nuremberg for crimes they committed against the peoples of Europe. These men became the embodiment of evil and provided a clear indication of the crimes carried out in the name of national security. What is often forgotten in the euphoric atmosphere of victory is those who sat in judgement. The judges representing the Soviet Union were themselves advocates of a barbaric political regime, which had organized the death and detention of millions of its own citizens. As for the USA, by dropping the atomic bomb on Hiroshima and Nagasaki the previous year, the Americans caused the deaths of 250,000 civilians. Churchill was considered a hero during the WWII period, but in 1919 he had advocated the use of chemical weapons (primarily against Kurds and Afghans), which killed tens of thousands of people, while later in 1943, in Bengal-India at least 3 million people are believed to have died as a direct result of Churchill's decisions and actions.

The irony of "evil" denouncing "evil" demonstrates the complexity of international relations and the fragility of ideology. The "enemies" the SS and the NKVD were tasked to destroy were themselves determined by political decisions of the ruling powers within their states, which suggests that no fixed definition could exist for a security threat, but rather it is simply what those in power declare it to be.

It is in this discourse of flexible threats that we place our most contemporary security issue, COVID-19. Enemies are usually carefully constructed to suit political strategy, whereas now states face a situation not of their creation or choosing. As is often the case, health and environmental crises can be disastrous and preventive measures are underfunded when compared with defence spending. Providing security in one sector is always at the expense of security in another. It is becoming increasingly obvious that our security is threatened in many different ways. We are also at risk of becoming less and less secure, as we attempt to secure our little corner, increase our prosperity and pursue our self-interest, as states pursuing their national security have done for centuries.

The concept of security is no longer interpreted narrowly - it is no longer understood as security of territory from external aggression, protection of national interests or global security from the threat of a nuclear holocaust. The security of people in their daily lives involves a child that did not die of starvation or through lack of medicine. It is a disease that did not spread, a job that was not cut, a dissident who was not silenced and a right that was not violated. Security is indivisible and universal, applying to the wealthy, to the poor, to westerners and easterners, people of all religions, cultures and races. It is also interdependent, as local insecurities can cross borders and have global implications. Lastly, and most importantly, in the 21st century security is people-centred: in UN terms, it is "freedom from fear, freedom from want". War, poverty, exploitation, imperialism, insurgency, as well as state violence, threaten not only the survival but also the dignity of millions of people. The harm can come as death, illness, starvation, homelessness, bereavement or trauma. It can be harm to personal safety, to basic needs and to freedom - of movement, to a language, to a culture, for self-expression. Fear, poverty and inequality, and fundamental threats to human security in people's day-to-day existence.

The seven categories of human security are identified by the UN as economic, food, health, personal, community, political and environmental. 
Vol. 7, No. 1, 96-98.

- Economic security means having an assured income, but also public safety net measures ensuring income to those unable to obtain one.

- Food security requires adequate access to food, physically and economically.

- Health security means having access to health care and protection against diseases.

- Personal security addresses threats from physical violence.

- Community security is the security individuals get within a group, establishing a sense of belonging and identity rooted in shared practices and values.

- Political security requires the freedom to be governed in a way that respects basic human rights, protected by democratic institutions in which individuals are given a voice.

- Environmental security addresses the environmental challenges posed by climate change, deforestation, the damage done to the eco-system, desertification and by human conflict.

21st century perspectives on security focus on the protection of the vital core of all human lives in ways that enhance human freedoms and fulfilment. Security means freedom from impoverishment, pollution, hunger, homelessness, ill health, abuse of power and illiteracy. As we marked the 17th anniversary of the invasion of Iraq, we continued to see the impact of that invasion on the security of the Iraqis. For 17 years now the people of Iraq have endured insecurity in all sectors: the checkpoints and walls, the curfews, poverty, lack of medicine, explosions and shootings as they shop, when going to work, waiting in queues, protesting, attending weddings and funerals. And, for the first time in the 21st century, the UK is witnessing the trauma of isolation, of fear, of food scarcity. At a time when our children's education is threatened, when we are barely able to provide for the sick, for the elderly and for those who are out of work, we are reminded of all those people who have experienced years of hardship, of terror and of trauma. We know a little of how it feels to fear going to the market, to fear going to a funeral, to fear sending our young to school, to fear becoming ill and to fear becoming broke.

What the spread of COVID-19 is showing us is that our security does not consist of staying safe from invaders alone. Or in staying alive. Living in fear threatens every aspect of society, every aspect of life: the young and the old, food and medicine, work and entertainment, school and play, our sense of joy and, when we can't even comfort the dying, our sense of loss. We now understand that threats do not just exist outside our borders and do not always carry weapons.

The cost of retaining staff and businesses will likely see the UK fall into yet another recession, forcing government spending cuts and tax rises in an attempt to regain control of the national purse. Health security has been prioritized at the expense of economic security and will create another series of challenges for the state apparatus to tackle. Economic security, as it begins to be prioritized, will have an impact on health security, with the looming threat of a second wave of COVID-19. Previous rivalries between the USA and China are likely to increase as both states attempt to gain greater influence. As is so often the case in "Cold Wars", proxy wars will become more common, with the battlefields being our highstreet or broadband providers, as much as the high seas of the South Pacific.

As the virus becomes more manageable, current alliances will be tested with countries looking to protect national interests. The European Union, NATO and the UN will now be forced to take action against expansionist policies. Member nations will be forced to manage the cost of continuing their commitments to defence with economic recovery. For democratic countries, the challenge of developing an effective strategy to the pandemic with a loud media and multi-party system may prove hard when compared to authoritarian styles of governance. Public opinion has proven to be a constraint for all styles of government, and public health will unify people against a state that fails to achieve results. 
What is the myth of security? It is that all categories can be protected or assured at the same time. What is becoming increasingly apparent is that when one aspect of security is prioritized, another suffers. When national security becomes a priority for the state, it is done so at the cost of international security, whether the ideology that has justified it is nationalism, communism, fascism, imperialism or is inspired by religion. What the COVID19 health crisis has demonstrated is that prioritizing health security comes at a price. And when eventually economic security and prosperity are once again at the top of the agenda, health, political and environmental securities will take a back seat. COVID-19 has made us not only question the meaning of security, but also its chances of success. 